\title{
Labour
}

Journal of Canadian Labour Studies

Le Travail

Revue d'Études Ouvrières Canadiennes

\section{The Left in the United States and the Decline of the Socialist Party of America, 1934-1935}

\section{Jacob A. Zumoff}

Volume 85, printemps 2020

URI : https://id.erudit.org/iderudit/1070907ar

DOI : https://doi.org/10.1353/1lt.2020.0006

Aller au sommaire du numéro

Éditeur(s)

Canadian Committee on Labour History

ISSN

0700-3862 (imprimé)

1911-4842 (numérique)

Découvrir la revue

Citer cet article

Zumoff, J. (2020). The Left in the United States and the Decline of the Socialist Party of America, 1934-1935. Labour / Le Travail, 85, 165-198.

https://doi.org/10.1353/llt.2020.0006
Résumé de l'article

Dans les premières années de la Grande Dépression, le Parti socialiste américain a attiré des jeunes et des intellectuels de gauche en même temps qu'il était confronté au défi de se distinguer du Parti démocrate de Franklin D. Roosevelt. En 1936, alors que sa direction historique de droite (la «vieille garde») quittait le Parti socialiste américain et que bon nombre des membres les plus à gauche du Parti socialiste américain avaient décampé, le parti a perdu de sa vigueur. Cet article examine les luttes internes au sein du Partie socialiste américain entre la vieille garde et les groupements «militants» de gauche et analyse la réaction des groupes à gauche du Parti socialiste américain, en particulier le Parti communiste pro-Moscou et les partisans de Trotsky et Boukharine qui ont été organisés en deux petits groupes, le Parti communiste (opposition) et le Parti des travailleurs. 


\section{FROM OTHER SHORES / DES NOUVELLES VENUES D'AILLEURS}

\section{The Left in the United States and the Decline of the Socialist Party of America, 1934-1935}

\section{Jacob A. Zumoff}

INTERNATIONAL CAPITALISM teetered in crisis during the 1930s, amid the misery caused by the Great Depression and the brutality of fascism in Europe. Many workers and intellectuals around the world responded by gravitating to the radical left, seeking an end to the capitalist system. This was most notable in countries like Spain, in the midst of a civil war that posed the possibility of revolution, but it was also reflected in traditionally more conservative anglophone North America, where unemployment soared and the future under capitalism appeared grim. The Spanish Civil War, Italian Fascism, German Nazism, and the inaction of capitalist governments to address the Depression further radicalized many workers and intellectuals.

In both Canada and the United States, leftists fought to revitalize the labour movement, struggling for industrial unions in the face of violent repression. In both countries, Communist parties affiliated with the Communist International (Comintern) were central to this upsurge in workers' struggle and to building the labour movement of the 1930s. The Communist Party of Canada (CPC) grew from a low point of fewer than 1,400 members in 1931 (when the party was essentially illegal) to a membership of 5,500 by July 1934 . Still, the CPC was overtaken in importance on the left by the Co-operative Commonwealth Federation (CCF), a vaguely social-democratic farmer and labour organization founded in 1932. In the United States, by contrast, the Communist Party (CP) overtook the traditional social-democratic party, the Socialist Party (SP), in terms of both size and influence, as many workers and intellectuals moved to the left during the 1930s. The height of the American Communist Party's influence occurred in the later 1930s. Although still dwarfed by the capitalist yet liberal reformist Democratic Party, the CP was 
the largest left-wing organization in the United States, with roots in many of the most important industrial unions of the period. ${ }^{1}$

In both countries, amid the pressure of such international and domestic developments, the left was in political and organizational flux. In the early 1930s, none of the established left-wing organizations could claim the loyalty of most workers, even most militant workers. As James P. Cannon, a leading US Trotskyist, recalled, "Little sects and cliques of individuals and their friends, representing quirks and vagaries of various kinds, were a common feature of the times. The movement was going through a period of pulverization, of pulling apart, until a new rise in the class struggle and a new verification of programs on the basis of world experiences could lay the ground for integration once again." ${ }^{2}$ For those coming to political consciousness, it was unclear which group claiming the heritage of Marxism offered a revolutionary way forward.

This article examines how groups to the left of the SP in the United States reacted to that party's political disintegration in the mid-1930s. Unlike the CCF in Canada, the SP had organizational continuity as the traditional socialdemocratic party in the United States since the turn of the century. While the SP had been the broad church of the American left during the 1910s, in the intervening years it had given birth to an array of more radical progeny, each professing sympathy with the Bolshevik Revolution of 1917 . The CCF voiced little of the Marxist rhetoric of the SP. As Gad Horowitz put it, "No portraits of Marx hung in the CCF convention halls. 'Onward Christian Soldiers' was more likely to by sung than the Internationale."

By the mid-1930s, the SP was again in crisis. More left-wing Militants (as they were known) sought to revitalize the party, with the assistance of the party's new standard bearer, Norman Thomas. In reaction to this leftward movement, the sP's traditional reformist leadership, the so-called Old Guard, sought to maintain control of the party. Factionalism was reaching a point in which the sp could not remain united, and in 1936, the Old Guard split from the party and formed the Social Democratic Federation (SDF).

1. The standard work on Canada in the 1930s is Michael Horn, ed., The Dirty Thirties: Canadians in the Great Depression (Toronto: Copp Clark, 1972); see also Bryan D. Palmer, Working-Class Experience: Rethinking the History of Canadian Labour, 1800-1991 (Toronto: McClelland \& Stewart, 1992), Chap. 5. Membership numbers from the CPC are from Ivan Avakumovic, The Communist Party in Canada: A History (Toronto: McClelland \& Stewart, 1975), 66, 90. On the early history of the CCF, see Norman Penner, From Protest to Power: Social Democracy in Canada, 1900-Present (Toronto: James Lorimer, 1992), Chap. 4. On the eclipse of the CPC by the CCF, see Ian McKay, Rebels, Reds, Radicals: Rethinking Canada's Left History (Toronto: Between the Lines, 2005), 169.

2. James P. Cannon, The History of American Trotskyism (New York: Pioneer Publishers, 1944), 190.

3. Gad Horowitz, Canadian Labour in Politics (Toronto: University of Toronto Press, 1968), 26. 
Central to the development of the SP in this period were the pro-Stalin Communist Party and the two groups that had been expelled from it in the late 1920s: the pro-Bukharin Communist Party (Opposition) (CPO), led by Jay Lovestone; and the Trotskyist Workers Party (w P), led by Cannon. All of these groups could trace their lineage to Lenin's fight for a new Communist International in the face of the social-democratic Second International's refusal to oppose the First World War and the support of many socialist parties for the war efforts of their own governments. By the 1930s these three groups had fundamental political differences, especially on the question of whether building socialism in the Soviet Union alone was possible (as Stalin insisted) or whether extending the Bolshevik Revolution was necessary (as Trotsky argued).

The political landscape in the United States was, of course, different from that in Canada, much less Europe. ${ }^{4}$ Besides the differences between the CCF and the SP, there was no significant Lovestone group in Canada, and the supporters of Trotsky were weaker. ${ }^{5}$ It is beyond the scope of this article to attempt to explain why the CCF overtook the CPC in significance and influence in the English Canadian workers' movement in the 1930, whereas in the United States the Communists overtook the SP. ${ }^{6}$ Nonetheless, by examining how left-wing groups in the period interacted, and experienced conflict, with one another, this article will draw useful parallels for comparative historical research on left-wing political movements in the 1930s.

As the American Socialist Party disintegrated, the groups to its left sought to recruit left-wing Socialists; however, these groups had different perspectives. First, the CP denounced the "social-fascist" sp from the left, claiming that there was no difference between social democrats, reformists, and fascists. Then, in anticipation of the popular front, it denounced the SP from the right, for preventing antifascist unity by standing its own candidates. Lovestone's group, which had significant political influence among the far-left wing of the SP, seemed best positioned to recruit from the splintering party. However, by the

4. Most of the attempts to deal with the historiography of Communism treat either the United States or Canada but not both. One attempt to deal with all of anglophone North America and Britain is Bryan D. Palmer, "How Can We Write Better Histories of Communism?," Labour/Le Travail 83 (Spring 2019): 199-232.

5. In this period, both the Lovestoneites and the Trotskyists in Canada were effectively extensions of the larger groups in the United States. On the followers of Lovestone in Canada, see Robert J. Alexander, The Right Opposition: The Lovestoneites and the International Communist Opposition of the 1930s (Westport, CT: Greenwood Press, 1981), 253-258. For a sketch of the early supporters of Trotsky in Canada, originally written in the 1970s, see Ian Angus, "Two Essays on Trotskyism in Canada in the 1930s," Socialist History Project, January 2007, http://www.socialisthistory.ca/Docs/History/Angus-T30s.htm.

6. The workers' movement in Québec is likewise far beyond the scope of this article, but see Marcel Fournier, Communisme et Anticomunisme au Québec, 1920-1950 (Laval: Éditions Coopératives Albert Saint-Martin, 1979). 
end of 1935, Lovestone seems to have abandoned hope of recruiting significant numbers of Socialists. The Trotskyists, in contrast, became more involved in the sp, reflecting the influence of Trotsky's concept of the "French Turn," that is, entering social-democratic organizations to win leftward moving socialists to Trotskyism. In 1936, after the Old Guard had left the sp, the Workers Party entered the rump Socialist Party. In 1937, the Thomas leadership expelled the Trotskyists. By this time, however, Cannon and his supporters had recruited a significant number of Socialists, especially youth members. By examining this history, the current article critically maps the changes in both the American SP and the groups to its left in the early 1930s - changes that helped set up the later Trotskyist entry into the party.

\section{The Socialist Party in the 1930s}

The American SP, from its founding in 1901, was weaker than its counterparts in other industrialized countries. It never became a mass party like its comrades in Europe; had no organic links to the American Federation of Labor (AFL), the main trade-union federation; and never threatened the power and influence of the two major capitalist parties. Almost from the party's foundation, its leadership was dominated by those who focused on reforms, while leftists who sought the revolutionary overthrow of capitalism were less influential. Nonetheless, the party's official program was more or less based on Marxism, with its emphasis on class struggle and socialism. This created a recurring problem: at times of increased social struggle, politicized workers and intellectuals swarmed to the SP, taking its Marxism as good coin, setting up another conflict between reformists and revolutionaries in the party. This led to splits in 1912 and 1914, amid labour struggle led by the Industrial Workers of the World ( $\mathrm{IWw}$ ). The reformist leaders of the sp purged the left wing, which was represented by Iww leader William Haywood. A similar process happened again in 1919 and 1920, amid the SP's formal opposition to the First World War and enthusiasm for the Bolshevik Revolution. Again, the SP leadership purged the left wing, members of which went on to found the Communist Party. ${ }^{7}$ In Canada, the formation of the CPC gutted the Socialist Party, which disbanded in $1925 .{ }^{8}$ The rump American Socialist Party continued, weakened but with its leadership firmly convinced in its opposition to Bolshevism.

7. On the development of the left wing within the Socialist Party, see Ira Kipnis, The American Socialist Movement, 1897-1912 (New York: Columbia University Press, 1952); Theodore Draper, The Roots of American Communism (New York: Viking, 1957), Chap. 1; Jacob A. Zumoff, The Communist International and US Communism, 1919-1929 (Leiden: Brill, 2014), Chap. 1.

8. Ian Angus, Canadian Bolsheviks: The Early Years of the Communist Party of Canada (Montréal: Vanguard, 1981), 76. 
After the 1919 and 1920 splits, the remaining Socialists moved to the right. In 1924 they did not run their own candidate for US president, supporting a capitalist politician, Republican Senator Robert La Follette. Two years later, Socialism's perennial standard bearer and left-wing conscience, Eugene V. Debs, died, leaving the sp leadership in the hands of the Old Guard, such as Morris Hillquit. ${ }^{9}$

In 1928, the SP's presidential candidate was Norman Thomas. Trained as a Presbyterian minister, he had been a prominent liberal for a decade, including a stint as associate editor of the Nation. In the face of the Old Guard's sentimental attachment to Marxist rhetoric, by the late 1920s Thomas was leading the SP toward more open reformism. In 1929, he succeeded in getting a reference to the class struggle removed from the party's membership application. ${ }^{10}$

Then, in October 1929, the stock market crashed. The Depression swelled the ranks of the party, from 9,560 members in 1929 to 20,951 members in 1934. ${ }^{11}$ Many of these new Socialists considered themselves revolutionary Marxists and became the core of what became known as the Militants. These Militants were politically heterogeneous, including pacifists (like Devere Allen) and more radical leftists. The original Militant core was formed in New York City in April 1930 with a platform that advocated establishing Socialist caucuses in the unions, issuing Socialist propaganda directed at the masses, and striving for a daily Socialist newspaper. ${ }^{12}$ To Thomas and his supporters (called Progressives), these Militants offered the potential to topple the sclerotic Old Guard.

In a recent article, Bryan Palmer describes the SP at this time as "caught in the vice-grip of demise" and "all but moribund." 13 Yet, Palmer's analysis seems to flatten out the contradictory political situation within the SP, which prompted its leftist critics to increase their attention to the party. Like the rest of the left, the SP was in flux, and where it would end up was not clear. Rather than being moribund, the SP in 1934, 1935, and 1936 was a petri dish of different political tendencies, each struggling with the others. To many, the party appeared to be entering a period of resurgence, not decline - even if we now know this was not the case.

As a whole, the SP was what Trotsky labelled "centrist," an eclectic mixture of revolutionary-sounding phrases and reformism. As Trotsky wrote in

9. Robert J. Fitrakis, The Idea of Democratic Socialism in America and the Decline of the Socialist Party (New York: Garland, 1993), 161-162.

10. Fitrakis, Idea of Democratic Socialism, 165; David A. Shannon, The Socialist Party of America: A History (New York: Macmillan, 1955), 207

11. Shannon, Socialist Party of America, 250.

12. Gilles Vergnon, "Le Socialist Party of America au début des années trente," Cahiers Léon Trotsky 27 (September 1986): 29.

13. Bryan D. Palmer, “The French Turn in the United States: James P. Cannon and the Trotskyist Entry into the Socialist Party, 1934-1937," Labor History 59, 5 (2018): 630. 
February 1934, "Never has centrism yet played to such an extent as now with all the colors of the rainbow, because never yet have the ranks of the working class been in such ferment as at the present time. Political ferment, by the very essence of the term, means a realignment, a shift between two poles, Marxism and reformism; that is, the passing through the various stages of centrism."14 In fact the SP did not remain a unified party. In 1936, it was still not clear which of the potential Socialist parties - the revolutionary left-wing one, the centrist one, or the reformist Old Guard one - would gain control of the party. Only political struggle, including that between the SP and the rest of the left, would eventually clarify this question.

\section{The Rise of the Socialist "Militants"}

At the 1932 SP Convention in Milwaukee, Thomas and the Militants battled the Old Guard in what the New York Times called "one of the most bitter factional battles in the history of American socialism."15 In anticipation of the convention, Devere Allen, Jack Altman, Upton Sinclair, and others issued a pamphlet titled A Militant Program for the Socialist Party of America: Socialism in Our Time. Formally opposing reformism, this manifesto stated that "it is a fundamental principle of Marxism that Socialism cannot be achieved as a series of reforms within the framework of the Capitalist State." The pamphlet "heartily endorse[d] the efforts of our comrades in Russia to create the foundations of a Socialist society and applaud their remarkable success. At the same time," it continued, "we set ourselves firmly against dictatorship in this country as long as democratic means of transition to a Socialist society are still available."16

Many Progressive supporters of both Thomas and the Old Guard were being pulled out of the SP altogether, attracted by bourgeois reform politics in the New Deal era. After Fiorello La Guardia was elected mayor of New York in 1933, several SP members accepted jobs in his administration. In California, Sinclair quit the party in the fall of 1933 to run for governor on the Democratic Party ticket, and many Socialists followed him. ${ }^{17}$ The exodus of such reformists

14. Leon Trotsky, "Centrism and the Fourth International," 22 February 1934, in Writings of Leon Trotsky, 1933-34 (New York: Pathfinder Press, 1972), 232.

15. “Socialists in Clash; Hillquit Is the Winner," New York Times, 24 May 1932. The immediate issue was whether Hillquit should remain the party's chairman, which the Old Guard supported. In the course of the debate, the issue of anti-Semitism was raised when one Thomas supporter from the Midwest implied that Hillquit, a foreign-born New York Jew, was less "American" than his factional opponents.

16. A Militant Program for the Socialist Party of America: Socialism in Our Time, 1932, box 22, folder 4, Daniel Bell Papers, Tamiment Library, New York University (NYU) (hereafter cited as DBP).

17. Fitrakis, Idea of Democratic Socialism, 171; Shannon, Socialist Party of America, 229-234. 
shifted the sp's centre of gravity to the left. The Old Guard was further weakened when Hillquit died in October 1933.

The June 1934 SP convention in Detroit was the next major showdown. In the lead-up to the convention, the Militants produced a pamphlet, Towards a Militant Program for the Socialist Party of America. This pamphlet argued that the Old Guard was too staid and too tied to AFL leadership. The pamphlet further alleged that many in the Old Guard saw Roosevelt's New Deal policies, such as the National Recovery Administration (NRA), eventually leading to socialism. The Old Guard, the Militants argued, "accepted the N.R.A. at its face value" and "believed that the basic difficulty with the N.R.A. was in the method of its administration, and that it would service its original purpose" if placed in more sympathetic hands. The Militants argued that "the N.R.A. is not a step towards socialism." They also criticized the craft-union emphasis of the AFL and supported industrial unionism - an issue at the centre of the civil war in the labour movement in the 1930s. ${ }^{18}$

The statement also criticized the Old Guard's focus on democracy: "The first task of the Socialist movement is the achievement of state power, and the question of the means to be followed is purely one of expediency." There are benefits to trying to obtain power through democracy, the statement argued, and dangers in extraparliamentary roads to socialism. "But whatever the difficulties of the extra-parliamentary method, the Socialist movement must be prepared to utilize it since the outstanding lesson of the post war revolutionary experience in Europe shows that where democracy becomes a real danger to capitalism, capitalism itself seeks to abolish it." The pamphlet continued, "The working class will either have to fight its battles outside of Parliament, in the streets, shops or factories, or submit to open capitalist dictatorship, whether it be called fascism or by any other name."

The Militants took no side in the struggle between Stalin and Trotsky: "While we do not agree with certain aspects of the internal and international policies of the U.S.S.R. we recognize that it is the one county in the world where a proletarian revolution was successfully carried thru and maintained." The statement also called for "the introduction of a broader proletarian democracy inclusive of all working class parties and groups that accept the proletarian dictatorship."19

The Militants' program, in summary, was far to the left of the Old Guard.

\section{The 1934 Detroit Socialist Party Convention}

At тhe SP's 1934 Convention in Detroit, the Old Guard represented the right wing of the party and the Militant tendency represented the left wing.

18. Towards a Militant Program for the Socialist Party of America, May 1934, box 22, folder 4, DBP.

19. Towards a Militant Program. 
Thomas viewed the Old Guard as an obstacle to his remaking the SP as he wished and thus formed a bloc with the Militants to help dislodge them. ${ }^{20}$ Likewise, right-wing "sewer socialist" Dan Hoan - the mayor of Milwaukee since 1916 and a protégé of right-wing Socialist Victor Berger - supported the Militants at the convention out of resentment of the New York-based Old Guard. ${ }^{21}$

The main showdown at the convention involved the new Declaration of Principles. Drafted quickly by pacifist Devere Allen, the declaration was a hodgepodge of leftist rhetoric, pacifism, and reformism far to the left of the Old Guard stance. ${ }^{22}$ The section on war stated that Socialists "will meet war and the detailed plans for war already mapped out by the war-making arms of the government, by massed war resistance, organized so far as practicable in a general strike of labor unions and professional groups in a united effort to make the waging of war a practical impossibility and to convert the capitalist war crisis into a victory for Socialism." Even more galling to the Old Guard was the section on democracy. While reiterating the SP's "faith in economic and political democracy," the declaration continued: "If the capitalist system should collapse in a general chaos and confusion, which cannot permit of orderly procedure, the Socialist Party, whether or not in such a case it is a majority, will not shrink from the responsibility of organizing and maintaining a government under the rule of the producing masses." ${ }^{23}$

At the convention, delegates adopted the declaration by a vote of 99 to 47 . This was a victory for Thomas, who consolidated his power in the SP. The 1934 convention ensured that a split within the SP was inevitable, as all sides recognized. As Old Guard leader James Oneal put it in 1934, “The party has come almost to a standstill and it can make little advance so long as present conditions continue." 24 The New Leader and the Jewish Daily Forward, both controlled by supporters of the Old Guard, denounced the results of the 1934 convention almost immediately. ${ }^{25}$

\section{Fitrakis, Idea of Democratic Socialism, 173-175.}

21. Hoan's bloc with the Militants went back to the 1932 sp convention in Milwaukee, when the Militants and Norman Thomas supported Hoan's defeated bid against Hillquit for SP national chairman.

22. See Barbara E. Addison, "Pragmatic Pacifist: Devere Allen and the Interwar Peace Movement, 1918-1940," Peace E Change 29, 1 (2004): 93-94; James Burnham, "Socialists and the Coming War," American Socialist Monthly 5, 6 (1936): 24-28.

23. See the special issue of American Socialist Quarterly 3 (July 1934).

24. James Oneal, Some Pages of Party History (New York: James Oneal, 1934), 3. On Thomas' appreciation of an approaching split, see Norman Thomas to Friedrich Adler, 5 November 1934; on the Old Guard, see Julius Gerber to Norman Thomas, 2 March 1935, both in Norman Thomas Papers, Stephen A. Schwarman Building, New York Public Library (hereafter cited as NTP).

25. See the New York Militant pamphlet For Unity in the Socialist Party, 1934, copy, reel 29, 
The Old Guard, despite their socialist phrasings, had long before settled into trying to reform capitalism and work within the AFL bureaucracy. Over the next two years, more and more Old Guard supporters left the SP, many joining the La Guardia or Roosevelt administrations, openly supporting governments led by capitalist parties. The Oregon and Oklahoma state parties seceded from the national sp over the new declaration. The Daily Forward ended its $\$ 500$ monthly subsidy to the SP in January 1935; by the end of the year the party was $\$ 10,000$ in debt, and literature sales were down 40 per cent. ${ }^{26}$ Thomas sensed that the party occupied a precarious position, threatened by being overtaken on its left by the CP and on its right by liberal reformers. ${ }^{27}$

\section{The Politics of the Revolutionary Policy Committee}

The far-left wing of the SP was the Revolutionary Policy Committee (RPC). Its history is shrouded in mystery and has to be traced through materials scattered among different archives and through outlines drawn by contemporary observers. ${ }^{28}$ Taking its name from a pro-Communist grouping in the British Independent Labour Party, the RPC seems to have originated in early 1934 out of the broader Militant grouping. ${ }^{29}$ In March 1934 the RPC issued An Appeal to the Membership of the Socialist Party, stating forthrightly its support for "the dictatorship of the proletariat" as "an entirely new type of state based on workers' councils, historically suited to serve as the organs of liberation." The appeal also stated that in the case of "inevitable" war under capitalism, Socialists should "prepar[e] the working class to turn imperialist war into class war." 30

The RPC supported struggling within the craft-based AFL for a perspective of industrial unionism. The RPC denounced the NRA as "a gigantic attempt to use methods of planning - state capitalism - in the interests of the most powerful financial and industrial magnates." The RPC also stated in its appeal that Soviet Russia "is preeminent, unique among the nations of the world" and also that "the Socialist Party must pledge itself to defend the victories for Socialism which have been achieved in the U.S.S.R." The statement contained no analysis

Socialist Party Papers, William R. Perkins Library, Duke University, Durham, NC (hereafter cited as SPP).

26. Fitrakis, Idea of Democratic Socialism, 179-180.

27. See Norman Thomas to McLevy, Allen, Freese, Darlington Hoopes, Hoan, Benson, Bienmiller, n.d. [February 1935?], N TP.

28. The most complete collection of materials by the RPC that the author has found are in box

22, folder 9, DвP.

29. On the British RPC, see G. Rose, "Locality, Politics, and Culture: Poplar in the 1920s," Environment and Planning D, Society and Space 6 (1988): 156.

30. Revolutionary Policy Committee (RPC), An Appeal to the Membership of the Socialist Party, March 1934, box 22, folder 9, DBP. 
of rise of Stalin or his dispute with Trotsky. Interestingly, it addressed black oppression, which the Socialist Party had long ignored. After quoting Marx's famous statement (from Capital) that "labor cannot free itself in the white skin while in the black skin it is branded," the appeal called for socialists to "energetically fight against every form of race discrimination wherever it appears." 31 A month later the R PC printed a second edition, with more signatories, including Irving Brown and Roy Reuther. ${ }^{32}$ At the 1934 Detroit convention the RPC had between fifteen and twenty delegates. In return for the RPC lending its support to the Thomas-Militant bloc against the Old Guard, the convention elected one RPC supporter, Franz E. Daniel, to the SP national executive committee (NEC). ${ }^{33}$

The Old Guard were hostile to the RPC. Oneal denounced the RPC as "a party within the party" and warned that its emergence signalled that "there are Communists secretly in the party to capture it for Communism." ${ }^{34}$ In late 1934, the New York State sP expelled five RPC supporters in Buffalo. Thomas was, in his words, "very critical" of the RPC program, which he called "a direct advocacy of armed insurrection." ${ }^{35} \mathrm{He}$ saw a place for such left-wing elements in the "inclusive party" he desired but was concerned that the RPC would make it difficult "to hold the middle-of-the-road folk who are very much worried about the RPC." ${ }^{36}$ Thomas thus sought to reverse the expulsions on the condition that the RPC agree to tone down its rhetoric. ${ }^{37}$

\section{RPC, An Appeal to the Membership.}

32. An Appeal to the Membership of the Socialist Party, 2nd ed., April 1934, box 22, folder 9, DвP. Several R PC members were involved in the Highlander Folk School in Tennessee; see Robin D. G. Kelley, Hammer and Hoe: Alabama Communists during the Great Depression (Chapel Hill: University of North Carolina Press, 1990), 120.

33. This is from an estimate by Jay Lovestone in Workers Age, 15 June 1934.

34. Oneal, Some Pages, 19-20.

35. Norman Thomas to "Mary and Harry," 21 November 1934; Thomas to Francis Henson, 6 December 1934, both in NTP.

36. Norman Thomas to Mary Fox, note, n.d. [November 1934?], NTP; Thomas to Henson, 6 December 1934.

37. See the statement of the five expelled RPC members to the New York State Committee of the Socialist Party, 2 September 1935, that outlines their response to the accusations that they were advocating dictatorship and insurrection, and appeals their expulsion; in NTP. Thomas set out his views on the RPC in various letters from early 1935. See, for example, Thomas to Reverend Herman Hahn, 22 January 1935; Thomas to Robert Alexander, 25 January 1935; Thomas to Ernest D. Baumann, 28 January 1935 and 30 January 1935; Thomas to Clarence Senior and Dan Hoan, 30 January 1935, all in NTP. The Thomas papers also contain correspondence from the leadership of the Buffalo sp defending the expulsions. In late February, Thomas wrote that "a committee of the NEC is dealing with the matter and I think a satisfactory statement can be had from the RPC." Thomas to George M. Whiteside, 25 February 1935, NTP. 


\section{The Left and the Revolutionary Policy Committee}

An ARticle in the November 1934 issue of the RPC's Revolutionary Socialist Review, titled "RPC and the Communists," outlined four key issues on which the two groups differed: the question of social fascism; the concept of the united front from below; the CP's policy of dual unionism; and "the mechanical domination of the American Party by the Russian Party." 38 Although all of these criticisms would be in accord with the perspective of Jay Lovestone and his followers, the RPC was also critical of the Lovestoneites for insisting that their "job is to work within the Communist Party" and their "contention that the Communist International is the logical political home of revolutionary workers." Instead, the article stressed, "The R PC policy is to work where the workers are and to try to educate them to revolutionary socialism. Therefore, we believe we must work within the Labor and Socialist International."39

The RPC's criticisms of the Trotskyists were more severe. After Hitler's rise to power in March 1933, and the lack of resistance shown by the German Communists or the Comintern to the rise of fascism, Trotsky called for a new, Fourth International. The RPC opposed this call, asking, "If the two present internationals have failed, why should the workers expect a fourth not to fail?" The RPC criticized what it saw as the "mechanical domination" of the Trotskyist movement, "not of Stalin ... but of Trotsky." Most substantially, the RPC disagreed with the Trotskyist position that the Soviet Union under Stalin had degenerated, remaining a workers' state but one misruled by a bureaucracy that would require a political revolution to dislodge it. According to the RPC, this position was "perhaps the most reprehensible in the whole international radical movement," because it went "so far left - if that can be called left - that one meets the right and lends it negative aid and comfort." 40 Fundamentally, the RPC had a "family of the left" perspective, in which the differences among the self-proclaimed Communist groups did not justify the existence of so many groups: "The RPC will welcome the time when all of these various sections of the revolutionary movement will work together in one single revolutionary party, organized on the basis of democratic centralism," stated the Revolutionary Socialist Review article. "They can retain, if they

38. Starting in 1928, according to the Stalinist leaders of the Comintern, the capitalist world had entered a "Third Period" of revolutionary upheavals. During this period, the Communist Parties throughout the world argued that social democrats were "social fascists," twins of the fascists who used socialist rhetoric. The pro-Stalin Communist Parties also eschewed unitedfront actions with other working-class organizations (under the justification of seeking "united fronts from below only") and called on workers to leave the established unions and form small "red" unions. For Trotsky and his supporters, the third period was a major reason for Hitler's easy victory in Germany in 1933.

39. "RPC and the Communists," Revolutionary Socialist Review, November 1934, box 22, folder 3, DBP.

40. "RPC and the Communists." 
desire to do so, some of their pet differences if they are unified and unyielding in their struggle against the immediate dangers of war and fascism and solidified for the final conquest of power for the workers." ${ }^{41}$ This attitude, of course, could not explain how groups with differences on so many basic questions would be able to work together, nor how so many groups had developed in the first place.

\section{The Young People's Socialist League and Factionalism}

Many of the Socialist youth in America, grouped in the Young People's Socialist League (Y PSL), were to the left of the Old Guard leadership; as a result, the left-right divisions in the Socialist movement were most acute within the youth organization, which served as a microcosm of the SP as a whole. By 1932, the YPSL had some 3,400 members. ${ }^{42}$ Hal Draper, a Y PSL leader in New York City, recalled that the majority of the YPSL membership and leadership "considered themselves to be revolutionary socialists" and "the young Socialists constituted the left wing of a Socialist party which was itself rapidly going left throughout this period." ${ }^{33}$ Many Y PSL members and leaders alike joined the Young Communist League. ${ }^{44}$ The Communist-dominated National Students League advocated unity with the Socialist youth, forming the American Student Union in December 1935.45

The leftward tilt of the YPSL caused tensions, especially in Old Guarddominated New York. In March 1935 the Y PSL leadership denounced the New Leader, the New York-based paper of the Old Guard, and withdrew support of the paper. ${ }^{46}$ The New York City Socialist leadership responded by trying

\section{1. "RPC and the Communists."}

42. Tim Davenport, "Young People's Socialist League, 1907-1946," marxisthistory.org, n.d., accessed 3 February 2020, http://www.marxisthistory.org/subject/usa/eam/ypsl.html.

43. Hal Draper, "The Student Movement of the Thirties: A Political History," in Rita James Simon, ed., As We Saw the Thirties: Essays on Social and Political Movements of a Decade (Urbana: University of Illinois Press, 1967), 156, 158.

44. See the section on YPSL in "Report of the NEC to the National Convention," June 1934, reel 29, sp ; Harvey Klehr, The Heyday of American Communism: The Depression Decade (New York: Basic Books, 1984), 102; Randi Storch, Red Chicago: American Communism at Its Grassroots, 1928-1935 (Urbana: University of Illinois Press, 2007), 193. See also George Smerkin \& Sol Larks, From Young Socialists to Young Communists (New York: Youth Publishers, 1934); Daniel Bell, Marxian Socialism in the United States (Princeton: Princeton University Press, 1967), 163.

45. Draper, "Student Movement," 173; Robert Cohen, When the Old Left Was Young: Student Radicals and America's First Mass Student Movement, 1929-1941 (New York: Oxford University Press, 1993), 138-140. The fusion was between the National Student League and the Student League for Industrial Democracy (SLID), another Socialist Party youth organization. For the relationship between YPSL and SLID, see Draper, "Student Movement."

46. Bela Low, Algernon Lee \& Adrian Gambet ("Sub-committee on Y PSL") to Members of the 
to purge the YPSL of its left-wing leadership, going so far as to break into the group's office, according to the Trotskyist New Militant. ${ }^{47}$

In July 1935, the national leadership of the YPSL complained that the Old Guard was, for political reasons, rejecting members applying for sP membership in New York and that "the Greater New York Federation of our League is still not recognized by Local New York of the Party as its youth section." At the same time, a report by a committee charged with investigating the New York Socialist Party declared, "We found that to all intents and purposes, the Y.P.S.L. of the city of New York have been expelled from the local organization and are prevented from functioning as part of the local." In addition to the raid on the YPSL office, the Old Guard had stopped its subsidy to the group and had set up a new group, the Young Socialist Alliance (YSA), which the report called "a dual organization, in truth and in fact." 48

Shortly afterwards, the YPSL's Eighth National Convention in Pittsburgh elected Ernest Erber as the group's national chairman. Erber helped edit the Chicago-based Socialist Appeal, published by Albert Goldman, a former (and future) Trotskyist. ${ }^{49}$ The conference elected other Militants from New York and Chicago - including Gus Tyler - to leadership positions as well. ${ }^{50}$

In late August the New York executive committee agreed to reinstate the YPSL on the condition that it follow the decisions of the executive committee and that members of the YSA be allowed to join the YPSL with no disciplinary action. ${ }^{51}$ Nonetheless, it was clear that major political differences existed between the Socialist youth and the Old Guard leadership and that these could not be resolved within the same organization, foreshadowing the coming split within the SP itself.

\section{The Communist Party and Socialist Factionalism}

The GROW TH OF A LefT-W ING opposition within the Socialist Party attracted attention. Of all the groups to the left of the SP, the Communist Party seemed the most significant. It had the greatest membership and social weight among intellectuals and the labour movement and was the official representative of

YPSL of Greater NY, 21 March 1935, box 21, folder 5, Dвр.

47. Jack Altman to Paul Porter, 14 March 1935, reel 30, spP; "Report of Sub-Committee on Inquiry and Mediation in Memorandum prepared for NEC," 13 July 1935, reel 31, spP; "Force Yipsels Resign Post," New Militant, 29 June 1935; “Democracy Violent in S.P.," New Militant, 23 March 1935.

48. Winston Dancis, report on YPSL, 13 July 1935; "Report of Sub-Committee on Inquiry and Mediation in Memorandum prepared for NEC," 13 July 1935; both in reel 31, SPP.

49. Davenport, "Young People's Socialist League."

50. Joseph Carter, “Militants' Capture y psL Convention,” New Militant, July 1935.

51. Algernon Lee to Winston Dancis, 14 September 1935, reel 31, SPP. 
the Comintern and, through it, Soviet Russia. From late 1933 to the summer of 1935, Communist membership swelled from 18,000 to 30,000, and many thousands more people were sympathetic to the party. Through strikes like the 1934 San Francisco Bay Area longshore strike, Communists were establishing themselves in the industrial union movement. ${ }^{52}$

Keeping with the Comintern's "Third Period" position (which was echoed in other parties, including the CPC), in the early 1930s the Daily Worker denounced the Socialist Party as "social-fascist" (i.e. not fundamentally different than the fascists who wanted to destroy the workers' movement). Communists espoused the "united front from below," in which Communists were to carry out work with rank-and-file Socialists, against the wishes of the "social-fascist" sp leadership. The rise of Nazism in Germany created a desire for working-class unity against fascism among leftists internationally, and the Communists sought support among the sP ranks. Many left-wing Socialists were more open than the Old Guard to working with Communists. ${ }^{53}$

Yet, the Old Guard opposed any cooperation with the CP. ${ }^{54}$ In February 1934, the Old Guard-controlled New York executive committee decided that "party members are not to participate in any conference, meetings, debates or symposia in which communists participate or speak." ${ }^{55}$ Idiocies committed by the CP seemed to buttress the Old Guard's case - such as when party members heckled and sabotaged an SP-led demonstration in February 1934 at Madison Square Garden that had been called to protest suppression of the Austrian social-democratic movement. ${ }^{56}$ In preparation for the 1934 Detroit convention, the New York State committee of the SP passed a resolution that opposed any common work with Communists so long as the CP continued its "dishonest Communist maneuvers regarding the united front." ${ }^{7}$

The growing popularity of Communism increased the weight of the Communists' criticism of the Socialists while diminishing their interest in the SP. The most successful Communist Party criticisms dealt with the Sp's longstanding refusal to champion black liberation..$^{58}$ The Communists' forceful

52. Harvey Klehr \& John Earl Haynes, The American Communist Movement: Storming Heaven Itself (New York: Twayne, 1992), 73.

53. Klehr, Heyday, 102.

54. See the section titled "United Fronts" and the section on the Y PSL in "Report of the NEC," SPP; Klehr, Heyday, 102.

55. Julius Gerber to Clarence Senior, 19 February 1934, reel 29, SPP.

56. See M. S. Venkataramani, "United Front Tactics of the Communist Party (U.S.A.) and their Impact on the Socialist Party of America, 1932-36," International Studies 1, 2 (1959): 154-183, esp. 165-167.

57. "Resolutions Adopted by the State Committee of the Socialist Party New York for the Agenda of the Socialist Party National Convention to be Held in Detroit, May, 1934," reel 29, SPP.

58. Cyril Briggs, “Socialist Party Segregates Negro Workers in the South,” Daily Worker, 25 
denunciations of black oppression helped them recruit significantly among black workers and intellectuals, while the Socialists' long-standing lack of emphasis on the question made them less attractive.

In the lead-up to the Detroit convention, CP leader Earl Browder signed an open letter - titled "Open Letter to Socialist Workers by the Central Committee of the Communist Party" - inviting the Socialist ranks "to join with the Communist Party in a united struggle for the most immediate and pressing needs of the workers and toiling masses, against developing fascism and imperialist war." ${ }^{59}$ At the convention, the Communists distributed this letter and organized a fringe meeting. ${ }^{60}$ The CP's view of the convention is summed up in a Daily Worker article titled "No Basic Change in S.P. Policy despite Many New 'Radical' Phrases," which denounced the "hypocritical, demagogic role of the so-called 'left' groups, 'militants' and the revolutionary policy committee, the latter influenced and directed by the Lovestone group of renegades from Communism." The RPC, the article continued, was "attracting some of the healthiest, most militant rank and file elements in the S.P., who want a real struggle on a united front basis," but the group served "to prevent these honest workers from following the line of logical development - out of the S.P. and into the fighting ranks of the Communist Party." ${ }^{61}$ The next day, the Daily Worker ran an article that denounced the newly adopted Declaration of Principles, "whose chief characteristic is its unprincipled radical-phased demagogy." 62 The Militants, a later editorial contended, offered nothing more than "typical Social-Fascist reformism." ${ }^{63}$ Over the next weeks, the Daily Worker published several letters from Socialists - including mid-level organizers - who had quit the SP and joined the CP. According to the CP, these activists represented "the lost voices of the convention," who opposed the SP's politics but who were betrayed by the RPC and the Militants. ${ }^{64}$

The fusion of the Socialist and Communist Parties - referred to as "organic unity" - enjoyed less support among Socialists in the United States than those in France, where both groups were mass parties. ${ }^{65}$ Nonetheless, US Socialists

May 1934.

59. "Open Letter to Socialist Workers from the Central Committee of the Communist Party," Daily Worker, 26 May 1934. A copy of the letter, dated 28 May 1934, is in reel 29, SPP.

60. “Socialist Party's National Convention Opens in Detroit," Daily Worker, 1 June 1934.

61. "No Basic Change in S.P. Policy despite Many New 'Radical' Phrases," Daily Worker, 4 June 1934.

62. “S.P. Convention Ends; Bogus 'Left' Gains Control over Party," Daily Worker, 5 June 1934.

63. “The S.P. 'Revolutionary' Declaration,” Daily Worker, 7 June 1934.

64. Examples of these letters are printed in the Daily Worker, 9 June 1934; 14 June 1934; 15 June 1934; 16 June 1934; 19 June 1934.

65. Ronald Tiersky, French Communism, 1920-1972 (New York: Columbia University Press, 1984), 90. In 1934, the PCF had some 40,000 members while the sFIo had 125,000 members. 
debated what approach to take toward the CP, especially after the rise of Hitler exposed the bankruptcy of the approaches of both the Communist and Social Democratic Parties toward fascism in Germany. So long as the CP's concept of a united front was that Socialists should denounce their leadership and join the Communist ranks, there was little chance of major support among Socialists for increased work with the Communists. In anticipation of the popular-front conception of alliances between Social Democrats and Communists (and liberal capitalist parties), however, the CP softened its approach.

In June 1934, after the Detroit convention, Browder wrote to the SP NEC reiterating the Communist Party's "readiness to develop such a united front of struggle" and to "stand ready to meet with the National Executive Committee, or with any of the local organizations or groups." 66 The SP leadership was understandably resistant to approaches by those who had deemed them social fascists until several months before. ${ }^{67}$

Yet the possibility of collaboration with the CP divided the SP leadership. While Thomas was willing to work with the CP in certain circumstances, and the Militants and the RPC were more sympathetic still, the Old Guard remained unwilling to work with the Communists.

By this time, the Communists had overtaken the Socialists, at least by official membership statistics. While the SP had 19,121 members in 1935, the CP had 30,000. ${ }^{68}$ The growth in American CP membership stands in contrast to CPC membership in English-speaking Canada, where the party, after playing an important role in rebuilding the labour movement early in the Depression, was overtaken in influence by the CCF. In the aftermath of the Seventh Comintern Congress, the CP continued making overtures to the Socialists. In April 1935, Browder wrote to Thomas, proposing "a broad united May Day demonstration together with the Communist Party and all other Labor Organizations." ${ }^{69}$ In July, the International Labor Defense sought support from the Detroit Socialist Party in defence of Angelo Herndon, a black Communist facing the death penalty in Alabama; in October, the Communist Party in Manhattan sought Thomas' support for the campaign to free Herndon. ${ }^{70}$

On October 3, 1935, Browder reported on the Seventh Comintern Congress to a crowd of 20,000 at Madison Square Garden, including several thousand Socialists. Browder called for the "united action of Socialists and Communists

66. Earl Browder to Norman Thomas, 19 June 1934, quoted in Venkataramani, "United Front Tactics," 170.

67. See Norman Thomas to Earl Browder, 21 August 1934, box 111, folder 25, Communist Party papers, Tamiment Library, NYU.

68. Klehr \& Haynes, American Communist Movement, 73, 85; Shannon, Socialist Party of America, 250.

69. Earl Browder to Norman Thomas, 12 April 1935, NT P.

70. Z. Cohen to Clarence Senior, 17 July 1935; Senior to Cohen, 23 July 1935; both in reel 31, SPP; Bill Lawrence to Thomas, 23 October 1935, NTP. 
to build a Farmer-Labor party, to fight against fascism and war." He continued, "We are raising for discussion with the Socialist workers the problems of organic unity in one Party, of all those who want Socialism. ... We will place this slogan of the united action of all adherents of Socialism and their eventual unity in one Party in opposition to the slogan of the Old Guard leaders, which calls for a united front with the open supporters of capitalism, even with Hearst, against the Communists." ${ }^{71}$ Shortly after that, Browder wrote to the Comintern detailing the new approach to the SP. He noted that the CP had supported SP candidates in Philadelphia and Reading, Pennsylvania, and Bridgeport, Connecticut. Clearly, "in the weaker sections of the SP over the country," Browder wrote, "advances are being made toward local and State agreements for joint action of various kinds." 72 In a speech at a plenum of the Communist Party's Central Committee in mid-November, Browder declared that one of the main tasks of the party was "to secure united action between Socialists and Communists in the United States and to call upon the Second International to accept the proposals of the Communist International for world-wide united action against war." Browder made clear that the CP's main interest in the SP was "to give practical help to those who move towards unity of all progressive forces."73

A culmination of this approach came in late November 1935, when Thomas took on Browder in a debate billed as "Which Road for American Workers: Socialist or Communist?" More than 20,000 people attended the debate, which was held in Madison Square Garden. Although Thomas still rejected the overtures of the CP for "unity," his mere participation in an event with Communists angered the Old Guard. No doubt the Old Guard were not heartened by the event's description in the New York Times: "The Socialists and Communists joined in singing the 'International,' the 'Red Flag,' and 'Solidarity Forever.' At one point during the debate Mr. Thomas led in the singing." 74 The Old Guard

71. Earl Browder, "Seventh World Congress of the Communist International: Report of Earl Browder at Madison Square Garden, New York City, October 3, 1935," 515:1:3957, Comintern archives, Russian State Archive of Political History, Moscow (hereafter cited as Comintern archives). Material from Comintern archives was viewed from microfilm at Tamiment Library, NYU.

72. Earl Browder to "Dear Comrades Dimitrov, Manuilsky, Marty, and Randolph," 4 November 1935, 515:1:3749, Comintern archives.

73. [Earl Browder], "The Seventh World Congress, the Present Situation and the Tasks of the Party," report attached to Minutes of Central Committee, Communist Party, USA, 15-17 November 1935, 515:1:3744, Comintern archives. The report was given under the name "Craig" but it is clear that the author was Browder.

74. “20,000 Hear Thomas Point Way to Reds," New York Times, 28 November 1935. The transcript of the debate itself is available in the pamphlet Which Road for American Workers: Socialist or Communist? Norman Thomas vs. Earl Browder (New York: Socialist Call, 1936). Part of the appeal of the debate was financial: the CP agreed to let the SP take the proceeds from selling tickets, which was especially important since the Old Guard had largely stopped 
boycotted the debate and refused to carry out joint work with Communists. The New York City executive committee, controlled by the Old Guard, even tried to have Thomas and eight other Socialists (including Altman and Tyler) disciplined for violating SP rules. ${ }^{75}$ Throughout late 1935 and early 1936, the CP continued making overtures to the SP, suggesting holding similar debates in other cities and advocating a farmer-labour party for the upcoming elections that would comprise Communists and Socialists. ${ }^{76}$ Browder even proposed that Thomas run for president and Browder for vice-president. ${ }^{77}$

Ironically, just as the CP's pressure on the SP seemed to be bearing fruit, or at least causing fissures in the SP, the CP changed its formal position. At the Seventh Congress of the Comintern, held in Russia in July and August 1935, Communist parties were instructed to seek to build "popular fronts," not just with other sections of the workers' movement like social democrats but also with liberal bourgeois forces. In the United States, this meant supporting the liberal wing of the Democratic Party, represented by Franklin Roosevelt. Browder later recalled that his nominally independent campaign for president in 1936 was designed to "put up our own candidate but conduct such a campaign that would assure Roosevelt all votes under our influence except the diehard opponents of all 'capitalist' candidates who without a Communist candidate would switch to Norman Thomas or even the Socialist Labor party." ${ }^{78}$ The Socialists, on the other hand, while understanding that they had no chance of challenging Roosevelt's support, stood Thomas for president and used the campaign to contrast their program with that of the Democratic candidate. ${ }^{79}$

Suddenly, the CP attacked the Socialist Party from the right: by running for president as a Socialist, Thomas was (in Browder's words) aiding "fascist

funding the SP.

75. See Irwin Nussbaum, for the Grievance Committee, to Norman Thomas, 30 November 1935, N T P, with enclosed charges by Algernon Lee and Julius Gerber. Thomas refused to appear as requested by the Grievance Committee; see Thomas to Nussbaum, 2 December 1935, N TP. See also Thomas to Gerber, 8 October 1935, NT P. In this letter, written before the debate, Thomas defends the debate and notes that he had already debated various Communists, including William Z. Foster, Jay Lovestone, and Robert Minor. On the charges against the eight other Socialists, see Jack Altman to Clarence Senior, 1 November 1935, reel 31, SPP.

76. See Clarence Senior to Norman Thomas, 15 November 1935, NTP; Jack Altman to Clarence Senior, 13 November 1935, reel 31, SPP.

77. Venkataramani, “United Front Tactics," 176-177. The concept of a workers' and farmers' party in the United States is outlined in Georgi Dimitrov's speech at the Seventh Comintern Congress; see Georgi Dimitroff, United Front against Fascism (New York: New Century Publishers, 1945), 39-41.

78. Earl Browder, "The American Communist Party in the Thirties," in Simon, ed., As We Saw the Thirties, 234.

79. The Socialist Party papers at Duke University contain the correspondence for the 1936 campaign, demonstrating that the SP made great efforts at great expense to run Thomas. 
demagogues" by not uniting with Roosevelt against the "most dangerous enemies - the Liberty League, [Alfred M.] Landon, and [William Randolph] Hearst." 80 As Max Shachtman, a former Communist and then a leading Trotskyist, later observed, "In the Popular Front period the Communist movement, which had broken from the original socialist movement to the left, made such a wide sweep around, 180 degrees, that it stood to the right of the American Socialist Movement." ${ }^{11}$ Since the Comintern had adopted the popular front internationally, this was the case in many countries. Many leftwing Socialists saw the rise of the popular front as a betrayal. ${ }^{82}$ While the advent of the popular front blunted the CP's chances of recruiting left-wing dissident Socialists, it left the field wide open to the two main far-left groups outside of the CP: the Lovestoneites and Cannon's Trotskyists.

\section{The Lovestoneites and the Socialist Party}

Although largely forgotten today, the Communist Party (Opposition), led by Jay Lovestone, was a significant political force in the early 1930s. ${ }^{83}$ Lovestone had been a founder of the US Communist Party in 1919 and by the late 1920s was the leader of that party. When his faction lost the confidence of Stalin and the Comintern in 1929, the CP expelled Lovestone and about 300 followers. ${ }^{84}$ Politically, the Lovestoneites supported the Right Opposition led by Nikolai Bukharin.

The Lovestoneites (like Cannon's Communist League of America) claimed to be a Communist opposition group that opposed the program of the Comintern and the pro-Stalin official Communist leadership, while fighting to be readmitted to the $C P$. Their main appeal was that they opposed the excesses of the Third Period, such as organizing new Communist-led unions instead of working within the AFL, and the concepts of "social fascism" and the "united front from below."

80. Venkataramani, “United Front Tactics," 179.

81. "Reminiscences of Max Shachtman: Oral History, 1965," interview by Betty Yorburg, transcript, 61, Socialist Movement Project, Columbia Center for Oral History Collection, NXCP87-A1246, Rare Book and Manuscript Library, Butler Library, Columbia University, New York.

82. See Draper in the Socialist Appeal, October 1935, and Cannon in the Militant, May 1935.

83. The history of the Lovestone group is a topic still awaiting its historian. The only attempt at a standard history is Alexander, The Right Opposition. While useful, Alexander's work is often sloppy and relies heavily on interviews with Lovestone and his supporters, who had moved far to the right. A useful collection of Lovestoneite documents exists; see Paul Le Blanc \& Tim Davenport, eds., The "American Exceptionalism" of Jay Lovestone and His Comrades, 1929-1940 (Leiden: Brill, 2015). See also Ted Morgan, A Covert Life: Jay Lovestone, Communist, Anti-Communist, and Spymaster (New York: Random House, 1999); Bertram Wolfe, A Life in Two Centuries: An Autobiography (New York: Stein \& Day, 1981).

84. Zumoff, Communist International, 282. 
During the Third Period the Lovestoneites appealed to leftists unhappy with the CP. Their attractiveness was enhanced by their talented propagandists and organizers, many former party leaders. Their publication Revolutionary Age (later renamed Workers Age) was attractive and lively, covering social, political, and philosophical issues of the day.

Unlike Cannon and the Left Opposition, Lovestone's opposition to the official CP was not based on a principled, thought-out program; instead, the Lovestoneites were motivated largely by factional pique. As the CP moved to the right in the late 1930s, the Lovestoneites moved even further in that direction. In the long term, Lovestone and his followers distinguished themselves by their unprincipled manoeuvrings and the fact that by the late 1930s they had become allies of the AFL bureaucracy in fighting Communist influence. After the Second World War, Lovestone became a key figure in the Central Intelligence Agency's alliance with the AFL leadership to fight Communism in the European labour movement. Between 1934 and 1936, this process was not completed.

The Lovestoneites seemed best positioned to benefit from the growth of a left-wing movement in the SP. They represented a "halfway house" between social democracy and the official Stalinism of the CP. In 1933, Benjamin Gitlow - a founding member of the CP and a leading Lovestone supporter - split from the Lovestoneite $\mathrm{CPO}$, in part out of a desire to be more critical of the economic policies of the Soviet government. Gitlow's group seemed to break with many Lovestoneite positions and made overtures to Cannon and the Communist League of America. ${ }^{85}$ The next year, another leading Lovestone supporter, Herbert Zam, split. ${ }^{86}$

Both Gitlow and Zam joined the sp, and Zam became a leading Militant. ${ }^{87}$ By June 1935, both men were on the editorial board of the Socialist Call. ${ }^{88}$ Thomas welcomed Gitlow's and Zam's followers into the Socialist Party as a counterweight to the Old Guard. The Old Guard saw the former Lovestoneites as a threat. Louis Waldman wrote that Gitlow's group joining the SP "calls for an immediate statement of policy from every Socialist State organization eager to preserve the Socialist Party from being turned into a

85. James P. Cannon to All Branches, "Negotiations with the Gitlow Group," document 13869, Leon Trotsky exile papers, 1929-1940, Houghton Library, Harvard University, Cambridge, MA (hereafter cited as LTEP).

86. Both the majority and Zam documents are printed in Workers Age, 1 November 1933.

87. Alexander, The Right Opposition, 63-69.

88. Socialist Call Editorial Board, minutes, 3 June 1935, reel 30, SpP. 
Communist Party." ${ }^{99}$ This Old Guard unease was magnified by the widespread sense that the RPC was a Lovestone front. ${ }^{90}$

In the spring and summer of 1934 Workers Age wrote positively of the R PC. ${ }^{91}$ In mid-June, Workers Age featured a front-page article by Lovestone about the Socialist Party's Detroit convention, in which he denounced the Militants as the "Noah's Ark of the Convention," the "Militant menagerie," and the "rainbow group" - because "all colors of principle and policy went in making one picture of confusion, solidified by aspiration to office and hope for a 'new deal."' While more favourable toward the RPC, Lovestone criticized the group because it had "failed to measure up to the situation." 92 Another article in the same issue, penned by "an active member of the Socialist Party," added that the RPC - "the red hope of the left wing" - had "failed to pull itself out of the caucus rooms onto the convention floor." Still, this article ended on an optimistic note: "For the first time in nearly 15 years, political questions, and, in a limited manner, fundamental principles were discussed somewhat critically at an S.P. convention. ... It is in this sense that this convention of the Socialist Party has real political import to us." To SP members who were "honestly seeking more effective ways and weapons in the class struggle," Lovestone offered "a helping, comradely, hand to aid ... in getting to the true revolutionary path."93

Soon, however, Workers Age became dismissive of the SP, implying that the Lovestone group did not see the value of a sustained political fight within the party. In January 1935, when the SP expelled members of the RPC, Workers Age ran an article describing the SP's moving to the right, with the Militants following along. The lesson that the Lovestoneites drew from the expulsions was "that it is impossible to capture the Socialist Party as a party. We insisted that expulsions of revolutionary socialists occurred in 1919 and would recur." 94 Lovestone seemed to have forgotten that the left wing's precipitous split from

89. Quoted in Jack Ross, The Socialist Party of America: A Complete History (Lincoln: Potomac Books, 2015), 356.

90. See Clarence Senior to Norman Thomas, 20 November 1934, NTP. In an affidavit dated 25 April 1934, "Record of My Activities in the Communist Party Opposition (Lovestoneite)," an SP member claims to have secretly joined the Lovestone organization and met several times with Lovestone, who bragged about his influence in the SP and his group's "great deal of influence in drawing up of the first and second drafts of the R.P.C. program of the S.P." and that "Irving Brown was one of their men." While intriguing, this document - a copy of which is in box 22, folder 9, DBP - is still not decisive, given the lack of basic information about it. On the view that the RPC was a cat's paw for Lovestone, see Militant, 26 May 1934; Daily Worker, 4 June 1934; 9 June 1934. Daniel Bell, whose archives contain the most complete material on the RPC, called the group a "weird mélange of revolutionary romanticists and secret Lovestoneite agents." Bell, Marxian Socialism, 165.

91. Jay Lovestone, “Tendencies in American Socialism,” Workers Age, 1 May 1934.

92. Jay Lovestone, "Leftward Winds in the S.P.," Workers Age, 15 June 1934.

93. A.M., "A Socialist on the Convention," Workers Age, 15 June 1934.

94. Arnold, "Socialists Start Expulsions of Left," Workers Age, 26 January 1935. 
the SP in 1919 had divided the pro-Bolshevik forces and foreclosed struggle to win the Socialist ranks to Bolshevism. The next month, writing about a meeting of the Michigan SP, Workers Age again supported the RPC but stated that "the bankruptcy of the [Socialist] party is an obvious fact which earnest revolutionaries must recognize." 95

What concerns us here is not Lovestone's take on the divisions in the Trotskyists' ranks but that by the time that the Socialist Party was splitting apart, the Lovestoneites seemed to have lost interest in intervening and trying to win its more left-wing elements. Such an intervention, Workers Age implied, would by necessity be opportunist. The Lovestoneites did not ignore the SP, of course. In late July 1935, Workers Age published an article by Lovestone on developments in the party, in which he argued, "Within the thirteen months that have elapsed since its Detroit convention, the Socialist Party has been moving definitely to the right at an accelerated pace." Lovestone wrote that the RPC "will be doomed" unless it "breaks finally with the confused and compromising 'Militants' and wages an energetic struggle" and does "not hesitate to bring to bear the heaviest pressure for clarity in principle, for sound Marxist ideology." Yet the conclusion was, again, that the only thing for leftists in the SP to do was to quit their party and join Lovestone: "There is a virile revolutionary socialist (communist) force in the U.S. struggling to arouse the American working class to militant action. This force is the CPO." He added, "We urge workers in the SP - especially those in the trade unions - to join our ranks, to work closely with us in our efforts to infuse a militant spirit in the American labor movement." 96

\section{The Trotskyists and the SP}

The American Trotskyists' reaction to the deepening crisis in the Socialist Party was the opposite of that of the Lovestoneites. While originally standoffish toward this development, by 1936 the Trotskyists were seeking new ways to intervene in the political debates within the SP, with the goal of winning militants to their banner.

Cannon, a founder of the American Communist movement, had read a partial copy of Trotsky's criticism of the draft program of the Comintern when he was in Russia as a delegate to the Sixth Comintern Congress in 1928. This document, later published as The Third International after Lenin, had won Cannon over to Trotsky's analysis of the bureaucratic degeneration of the Russian party and state, which Stalin had justified ideologically through his dogma of "socialism in one country." Cannon smuggled Trotsky's document to the United States and there showed it to selected allies in the Communist Party. In October 1928 the CP expelled Cannon and two key

95. “Mich. SP Convenes, RPC Ranks Hold," Workers Age, 16 February 1935.

96. Jay Lovestone, “Now We Have Been Moved,” Workers Age, 27 July 1935. 
factional lieutenants, Shachtman and Max Abern, for Trotskyism. In May 1929, Cannon founded the Communist League of America (CLA), along with 100 former factional supporters. Shortly after this, the Comintern moved into the Third Period, which undercut many of the CLA's criticisms of the CP. The Communists' much larger size and their ability to wrap themselves in the prestige of the Soviet Union further weakened the CLA's attractiveness among dissident Communists. Cannon described the CLA's formative years in the early 1930s as its "dog days"; the CLA was almost torn asunder by factionalism in these years. ${ }^{97}$ By the end of 1933, the CLA had 26 branches throughout the country (except in the South) and some 350 members; the Militant claimed a circulation of $4,500 . .^{98}$

The perspectives of the American Trotskyists were heavily influenced by European developments. In June 1934 Trotsky proposed what became known as the French Turn. According to Trotsky, many workers and intellectuals had become radicalized by the Depression and the rise of fascism. Entering leftwing politics for the first time, these people were more likely to look to the established left-wing parties, the social democrats and the Stalinists, than to the small groups of the Left Opposition. This did not change the political nature of the Comintern or the Second International, but it did mean that sections of the membership in each saw themselves as revolutionary Marxists. Since the Stalinist parties were dedicated to the destruction of Trotskyists, Trotsky advocated that his followers join the social democrats, the French Section of the Workers' International (Section française de l'Internationale ouvrière, or SFIO). Trotsky did not believe that what Rosa Luxemburg had termed the "stinking corpse" of social democracy could be turned into an instrument for revolution, but he saw the possibility of crystallizing left wings with the aim of breaking them from reformism and forming new revolutionary parties. ${ }^{99}$

In 1933 and 1934, there was an uptick in class struggle in the United States. The CLA played a key role in the important Minneapolis truckers' strike. ${ }^{100}$

97. See Dog Days: James P. Cannon vs. Max Shachtman in the Communist League of America, 1931-1933 (New York: Prometheus Research Library, 2002).

98. Arne Swabeck, "Report of the Communist League of America (Opposition)," 15 December 1933, doc. 17298, LTEP.

99. Trotsky's views are outlined in Writings of Leon Trotsky, 1934-35 (New York: Pathfinder Press, 1972). In a discussion with Maurice Spector, Trotsky stated, "If we could enter the C.P., we should do so, of course, but it is impossible." "Conversation between S[pector] and T[rotsky] on American Question," end of February 1936, original in box 10, folder 4, Albert Glotzer Papers, Hoover Institution, Stanford University, Palo Alto (hereafter cited as AGP), copy in American Trotskyist Papers, 1928-1940s, Prometheus Research Library, New York (hereafter cited as ATP).

100. See Bryan D. Palmer, Revolutionary Teamsters: The Minneapolis Truckers Strike of 1934 (Leiden: Brill, 2014). The role of the Trotskyists in the 1934 Teamsters' strike, along with the strength of the Minnesota Farmer-Labor Party as one of the main capitalist parties in the state, made Minnesota unique in left-wing history in the 1930s. On this history, see N. Dylan 
That same year, the CLA fused with A. J. Muste's American Workers Party (AWP), which had led another strike earlier that year, the Toledo Auto-Lite strike. Muste was a former minister and an activist in the labour movement. In late 1933, his Conference for Progressive Labor Action became the AwP, proclaiming "the revolutionary struggle of the masses against the capitalist system which more and more depresses their standards of living" and calling for this struggle to be "inspired, coordinated, [and] carried to its goal, by the revolutionary political party." ${ }^{101}$ Out of this fusion came the Workers Party of the United States (WP). ${ }^{102}$

The ClA's fusion with the Aw P was in its own way an application of Trotsky's French Turn in that it provided an opportunity to win left-moving workers and intellectuals to the Left Opposition's program. As Shachtman recalled, "In general most of our people did regard the Aw Pers as centrists, but in line with the conception that we were now imbued with, that Trotsky had put forward: we unite with centrists who are moving to the left, and we facilitate by a maximum of intelligence and patience and flexibility their further evolution to the left." 103 While it gave the Trotskyists a much a stronger basis from which to grow, the WP itself was still faced with a much larger left wing in the Socialist Party. Cannon and Shachtman believed that Trotsky's French Turn was still applicable to the SP. Eventually, this would result in the Trotskyists' entry into the SP, in 1936. In the newly formed wP, however, many members, including Muste, opposed such an entry. Between the fusion with the AwP and the entry into the SP, a political struggle took place within the Trotskyists' ranks.

Historian M. S. Venkataramani asserts that "the American Trotskyites were, at that time, eagerly waiting for an opportunity to get a foothold in the Socialist Party." 104 Thirty years later, Shachtman was clear that no such early desire had existed: "We, however, saw a big change had taken place. The right wing was out. And the new and active elements we saw as very fine people. We did not have the idea of going into the SP. We were accused of that, but it

Boorman, "American Trotskyism and the Minnesota Farmer-Labor Party from Origins to 1936," MA thesis, San Francisco State University, 2017.

101. "An Open Letter to the American Workers Party," Militant, 27 January 1934. On Muste and his followers, see Michael Goldfield, The Southern Key: Class, Race, and Radicalism in the 1930s and 1940s (New York: Oxford University Press, 2020), 94.

102. See the editors' introduction to Max Shachtman, Marxist Politics or Unprincipled Combinationism? Internal Problems of the Workers Party (1936; repr., New York: Prometheus Research Library, 2000).

103. "Reminiscences of Max Shachtman: Oral History, 1963," interview by Stephen Chodes \& Thomas F. Hogan, transcript, 244-245, Socialist Movement Project, Columbia Center for Oral History Collection, NXCP87-A1249, Rare Book and Manuscript Library, Butler Library, Columbia University, New York.

104. Venkataramani, "United Front Tactics," 174. 
was absolutely untrue." He added, "We wanted, however, to establish contact with them, begin orienting them toward us."105

An examination of the Trotskyists' press indicates that they were following developments in the SP, but internal Trotskyist material shows that "entryism" was not the party's original perspective. In late 1933, Arne Swabeck reported that "there are trends today within the Young Peoples Socialist League and Socialist Party in a leftward direction but still undeveloped." He added that "a few of these small groups work closely with us" and especially highlighted the Illinois mine field. ${ }^{106}$

Although occupied with intervening in a strike wave and fusing with Muste, in 1934, the CLA, and later the WP, paid attention to developments in the SP. Before the Detroit SP convention, Cannon, writing in the Trotskyist newspaper the Militant, had commented on the RPC's pamphlet An Appeal to the Membership of the Socialist Party:

For the first time since 1921, a group of more or less influential party members takes issue with the reformist position on fundamental principle questions and approaches the standpoint of revolutionary Marxism, that is, of Communism. Declaring against any "middle road" and demanding that the Socialist Party change "its present principles and tactics," the new Left group attacks the traditional reformist policies of Social Democracy all along the line. ${ }^{107}$

Cannon noted that the RPC's document "is somewhat lacking in clarity and incisiveness on certain fundamental issues which permit of no ambiguity" and "also leaves other essential programmatic questions untouched and omits the necessary critique of the various groups and tendencies in the Socialist and Communist movements." But the crucial issue was that the emergence of the RPC "indicates the emergence of a substantial group in the Socialist Party which is obviously breaking with the policy and practice of social reformism." Cannon predicted, "If the group perseveres on this course it will undoubtedly attract the revolutionary elements of the party, especially the Socialist youth, and play an important role in the reconstitution of the revolutionary movement in America." ${ }^{08}$ Internally, Cannon was blunter, calling the RPC "a centrist group of a different kidney." According to minutes from a CLA national committee meeting, Cannon stated that the RPC "represents more clearly than any other current in the SP in the last dozen years the honest groping of revolutionary works toward communism. Its program, unsatisfactorily brief (far terser than that of the Militants, and even inferior to it in certain secondary points) is closer to the communist program. It carries a good deal of

105. “Reminiscences of Max Shachtman: 1963," 254-255.

106. Swabeck, "Report."

107. James P. Cannon, “The International Position of the Revolutionary Policy Committee," Militant, 12 May 1934.

108. Cannon, "International Position." 
Lovestone's ideological baggage, but the latter is so slight that an active, fermenting group, fraternally assisted by us, can throw off more if not all of it without too much difficulty."109

The Trotskyists were more critical of the RPC than were Lovestone's supporters, although less harsh than the CP. In June, the Militant ran an article on the RPC by Albert Glotzer. Although sympathetic, Glotzer noted that "the [RPC] group is made up primarily of the petty-bourgeois and intellectual section of the [Socialist] Party." For Glotzer, "The R.P.C. represents a serious movement within the S.P. towards Marxism, its program is not yet Marxism, but has moved a long way in that direction." He singled out the RPC's position on international social democracy, the state, the Soviet Union, and Stalinism. On the role of the social democracy, Glotzer wrote, "It is obvious that the R.P.C. orientates itself on the basis of the policy of reforming the Socialist Party and the Labor and Socialist International. There is not the slightest hint that the fundamental character of social democracy makes it impermissible to remain within its ranks. The possibility of a break is not even countenanced in the program." On the other questions, he noted, the RPC was silent. ${ }^{110}$ To influence the convention, the Militant published several articles; in addition to those by Cannon and Glotzer quoted above, a series of articles by Glotzer, titled "Before the Detroit Convention of the Socialist Party," dealt with the reformist social-democratic politics of the Second International. ${ }^{111}$

Cannon attended the SP convention as an observer. Afterwards, he delivered a report to a meeting of the National Committee of the CLA. In it he described the RPC as "a very weak and politically inexperienced group" that "did not appear as an independent group before the convention." According to Cannon, "the Lovestonites have one plant in the R.P.C.," while the "Stalinists have no influence and [are] withdrawing now what little they had in the S.P." According to the meeting's minutes, Cannon explained,

The perspective in the S.P. is not an immediate split. The Old Guard use the club of split and are succeeding in forcing the "Militants" into a retreat. It appears that the Lovestonites are driving for a quick split in order to get a little out of that for themselves. In proceeding to organize our national fraction, we should also assist in building the R.P.C. everywhere and gauge the opportune moment for the putting forward of our full position, for the new party, etc. ${ }^{112}$

The National Committee voted "to form a national fraction in the S.P. and the Y.P.S.L." and noted that "the immediate tactic for this fraction is to work

109. Cla National Committee minutes, 29 May 1934, ATP.

110. Albert Glotzer, "Positions of Conflicting Groups in the Socialist Party," Militant, 2 June 1934.

111. Albert Glotzer, "Before the Detroit Convention of the Socialist Party," Militant, 12 May 1934; 19 May 1934.

112. CLA National Committee minutes, 25 June 1934, ATP. Lovestone's followers are referred to as both "Lovestoneites" and "Lovestonites." 
within the R.P.C. as a left wing, to begin a concerted struggle to push it further leftward and to isolate Lovestonite and Stalinist influences. Where no R.P.C. groups exist and we have the opportunity we should form such a fraction within them." The meeting voted in favour of Cannon being "national organizer" for the fraction. The meeting also voted to use the CLA's press to "launch a systematic and furious campaign against the 'Militants"' as well as "a campaign in the S.P. for the demand that the S.P. break with the second International and come out with a new International (we make clear that we mean the Fourth International.)"113

During this time, the Workers Party regularly came into contact with members of the Socialist Party, particularly in two areas of work. First, the SP was active among the unemployed. According to the minutes of the Workers Party Political Committee (WPPC), in late 1934, Trotskyists and Socialists were active in North Carolina, New Jersey, Connecticut, Wisconsin, Florida, and Texas. ${ }^{114}$ Socialists and Trotskyists were also active in the "Sacramento Conspiracy Trial," in which eighteen radicals were tried on charges of "criminal syndicalism" for organizing migrant farmworkers in California's capital. Most of the defendants supported the Communist Party, but one, Norman Mini, had broken with the CP and was sympathetic to Trotskyism. The CP's legal defence arm, the International Labor Defense (founded by Cannon when he was a leading Communist), refused to defend Mini, so wP lawyer Albert Goldman did. The WP organized its own defence organization, the Nonpartisan Labor Defense (NPLD), and sought to form a united front with other groups, including the Socialist Party. ${ }^{115}$

The Workers Party recruited SP and YPSL members. The New Militant reported that W. W. Norris, state secretary of the Socialist Party and a member of the national executive committee of the RPC, had joined the Workers Party. ${ }^{116}$ In early January 1935, the WPPC passed the following motion: "Fractions should be created in S.P. and C.P. whenever possible and feasible in relation to our fundamental policy of building the W.P. by independent activity and as a subordinate tactic" to the "general policy ... to develop and crystallize the revolutionary Marxist currents in these organizations for their reunification with the W.P."117 The Communist Party, rather than the

\section{CLA National Committee minutes, 25 June 1934.}

114. Workers Party Political Committee (WPPC) minutes, 5 December 1934; 4 February 1935, both in ATP.

115. WPPC minutes, 28 January 1935, Aтр. On Mini, see his statement, “Criminal Syndicalist or Renegade," Militant, 23 March 1935.

116. “Norris, S.P. Leader Joins Workers Party," New Militant, 29 December 1934. Similarly, the New Militant reported that a Socialist from St. Louis joined the w P ("St. Louis Socialist Finds Workers Party Is Realistic," 9 February 1935) and later that twelve YPSL members joined ("NY Left Wing Leaves Y PSL and Joins w P," 6 April 1935).

117. WPPC minutes, 7 January 1935, ATP. 
Socialists, received more attention because Joseph Zack, a founding member of the $\mathrm{CP}$, had recently quit that organization to join the W P. ${ }^{118}$ Although the Trotskyists had a faction within the SP, their perspective was a short-term one. In February 1935 the WPPC approved a motion to set up a committee to follow "developments in the S.P. with particular reference to crystallization of left groups and the possibility in [the] near future of [a] split so as [to] orient the W.P. in the concrete task of assisting this process." ${ }^{119}$ Less than a week later, the W PPC decided that known supporters of the W P who were members of the YPSL should resign in three weeks if they were not expelled sooner. A member of the WP was to go to a Militant conference the next week and intervene along the lines that there was "only one road to socialism" as well as stress the "need to attack the right wing" and to advocate the perspective of "non-partisan labor defense." But, the motion added, this wP member "is not to expose himself." At the same meeting, Swabeck put forward a motion that WP supporters in the SP and YPSL should "orient themselves on a larger perspective" and "not withdraw until necessary." This motion was defeated. ${ }^{120}$

Less than a month later, the WPPC passed a motion that the Trotskyists' group of supporters should "work toward termination of its membership in SP and YPSL in two weeks and that at the end of that period call on revolutionary elements in the S.P. to join W.P." ${ }^{121}$ Shortly after that, the minutes record that the SP fraction "takes position that it is necessary for our contacts," with one exception: "to get out of S.P. as soon as possible." In response, Hugo Oehler stated, "Our aim must be to open up a struggle against the Militants on programmatic grounds to explain the true rule of these right centrists, to explode the concept that this new party (if it arrives) is a revolutionary party, to give political guidance to the real left elements in the SP by presenting polemics on program, and to help crystallize a left force within the Militants."

In response to this disagreement, the WPPC agreed to a motion by Cannon that the "secretariat [was] to meet with fraction and in interim no action be taken." ${ }^{122}$ However, the next meeting passed a motion that the fraction in the Socialist Party should resign immediately. ${ }^{123}$ In April 1935, eleven members of

118. WPPC minutes, 10 January 1935, Aтр. See “Zack Expelled From Workers Party," New Militant, 6 July 1935. Zack remained in the Trotskyist movement only a short time; by the late 1930s, he had become a friendly witness in the government anti-Communist hearings. On Zack's later trajectory, see his obituary: “Joseph Zack Kornfeder Is Dead; Ex-Official of U.S. Reds Was 65," New York Times, 4 May 1963.

119. W PPC minutes, 16 February 1935, Атр. This committee comprised Arne Swabeck, Max Shachtman, Ludwig Lore, and James Burnham (under the name West).

120. WPPC minutes, 21 February 1935, ATP.

121. WPPC minutes, 9 March 1935, ATP.

122. W PPC minutes, 28 March 1935, AтP. Cannon's motion was passed 4 to 3.

123. WPPC minutes, 1 April 1935, ATP. 
the SP and YPSL resigned from those organizations and jointly issued a leaflet announcing their allegiance to the Trotskyists. ${ }^{124}$

Nonetheless, the motions indicate constant interaction with the SP. In late April 1935, the secretariat voted to take "Mackenzie (member of the S.P.)" into membership in the Workers Party "on condition that he carry out the party policy in the S.P." and that this be coordinated by the wP's national office. ${ }^{125}$ The next week, there was a point on the agenda about the RPC at the WPPC meeting. The body set up a committee comprising of Cannon, E. R. McKinney, and Swabeck, to liaise with the RPC. The committee was instructed to focus on the Workers Party "attitude to the Comintern, its opportunistic line and relation to the Fourth International" and "the prospects of struggle in the S.P."126

A month later, this committee had met twice with its counterparts in the RPC (which by this time had renamed itself the Revolutionary Policy Publishing Association [RPPA]). The first such meeting was not fruitful because it reportedly "turned into argument with Lovestoneite sympathizer." But the second meeting, with " $\mathrm{X}$ " of the RPPA, was evidently more successful: X was moving closer to the WP. The identity of $\mathrm{X}$ is unclear, although the minutes noted that CP head Earl Browder had recently telephoned X to invite him to attend the upcoming Seventh Comintern Congress as an informal observer. X, who claimed 300 "direct contacts" and 2,000 "sympathizers," wanted to focus on discussions on France and the social patriotism of the CP. According to the minutes, "on question of tactics in S.P. Cannon advised X [to] dive deeper into S.P., [to] get rid of Lovestoneite stamp so that is not a case of a handful of individuals coming out but developing a left wing." $\mathrm{X}$ was instructed to write a "long article for RPPA" against the Comintern and Lovestone. Above all, the minutes stressed, "The tactic of driving deeper into S.P. is the important thing." 127

The minutes of the same meeting noted that "at present we haven't much contact among Militants" and reported "no sentiment among Militants toward us as a party at present." The wP had contact with somebody in the Militants (called "Y" in the minutes), but this person claimed that the "S.P. sees us as small group torn with internal contradictions and with a tendency to go into S.P." 128 In reference to "rumors to the effect that there are leaders and members of the W.P. who advocate that the W.P. should join or merge with the Socialist Party," a July 1935 article in the New Militant declared that such "reports are absolutely without foundation, that no leader or members of the W.P. advocate

124. Statement of resignation from the Socialist Party and the YPSL, [mid-April 1935], box 21, folder 5, DBP.

125. W P Secretariat minutes, 30 April 1935, Атр.

126. WPPC minutes, 6 May 1935, АтP.

127. WPPC minutes, 10 June 1935, ATP.

128. WPPC minutes, 10 June 1935. 
or have advocated any such program."129 Through 1934 and 1935 the Workers Party was oriented toward recruitment of individual disaffected Socialists, as shown in its press and public events, but WP members did not see themselves playing an active role within the crises-ridden SP itself.

\section{Conclusion: The Decline of the Socialist Party}

Meanwhile, factional warfare engulfed the Socialist Party. Thomas complained that the New York City SP "is now controlled by a narrow majority by an Old Guard which is sabotaging activity and has taken generally impossibilitist extreme right wing line." 130 A key issue was whether Socialists could carry out united-front action with Communists or supporters of the Trotskyists or Lovestoneites. The Old Guard accused these groups of infiltrating the SP and demanded that anybody supporting Communism be purged from the party. ${ }^{131}$ In December 1934, Louis Waldman, the Old Guard chairman of the New York State Socialist organization, declared, "All signs of the time point to the fact that the future of the Socialist party lies with the organized labor movement, and not with the Communists." Waldman and his supporters wanted to purge the SP of its left, and the Old Guard had particular animus toward the RPC. A memorandum presented by Waldman declared that the RPC had "a program which in all respects is identical with communism."132

The division was expressed in duelling newspapers. Unlike the Communist Party or most other left-wing parties, the Socialist Party did not have an official paper but relied on privately owned papers sympathetic to the party. ${ }^{133}$ The Jewish Daily Forward had long been friendly to the Old Guard, although it was not, strictly speaking, an SP newspaper. The New Leader became the voice of the Old Guard. In early 1935, Militant leader Jack Altman helped organize the Socialist Call as an alternative. The Call became a pole for left Socialists in New York and elsewhere; it soon garnered support from state organizations in California, West Virginia, and Massachusetts. ${ }^{134}$ In March 1935, Militants in New York submitted a fourteen-page document, titled "Statement to the National Executive Committee on the Conditions of the Socialist Party in the

129. "Plenum of N.C. of W.P. Spikes False Rumors," New Militant, 6 July 1935.

130. Norman Thomas to A. Sumner Thompson, 11 April 1935, NTP.

131. “Socialists Divided on Communist Group,” New York Times, 2 November 1934.

132. "Right Socialists Hint at Secession," New York Times, 2 December 1934. On Waldman, see Edward A. Gargan, "Louis Waldman, 90, Counsel to Labor," obituary, New York Times, 14 September 1982.

133. Jason D. Martinek, "Business at the Margins of Capitalism: Charles H. Kerr and Company and the Progressive Era Socialist Movement," Business and Economic History On-Line 8 (2010): 8, https://thebhc.org/sites/default/files/martinek.pdf.

134. See Jack Altman to Arthur McDowell, 31 January 1935, reel 29, SPP; Altman to Paul Porter, 12 April 1935, reel 30, SPP. 
State and City of New York," detailing attempts by the Old Guard to maintain control of the party apparatus against the wishes of the membership. "This is not a struggle between two groups in a section of the Party; it is a bitter guerrilla warfare waged by a defeated and disgruntled minority against the Socialist Party in the United States," the statement read. ${ }^{135}$

The SP national executive committee met later that month. While it absolved the RPPA of being a disloyal or dual organization, the NEC urged that all party publications, including those of the RPPA, "be closed to the advocacy of armed insurrection or any tactics expressed in phrases of similar purport; and, further, that advocacy of armed insurrection or similar methods shall be deemed incompatible with membership in the Socialist Party of the United States." The RPPA replied as follows: "The decisions and the lack of decisions, emanating from this last meeting definitely establish the present NEC as a new old guard with absolutely no possibility of pretension as a left wing or revolutionary force. It is high time to realistically evaluate the pompous and fantastic claim that the party - through the Detroit convention and the election of the present NEC has taken a sharp turn to the left!" Indeed, the NEC showed that it was dedicated to "attempts to carry out its tasks of hunting down those who recognize that the class struggle is more than a tea party" at the same time that "red-baiting is fast becoming the popular pastime of reactionaries and their publications." ${ }^{36}$ Although the RPPA did not mention it, the purge of the sp left wing in 1935, for advocating "armed insurrection," recalled the 1912 purge of William D. Haywood, the leader of the IWW and a member of the SP'S NEC, for his support of "sabotage." In both cases, amid an upsurge of class struggle, the right wing of the SP sought to prune the party's left wing. ${ }^{137}$

The danger of a split was such that Friedrich Adler, from the Labour and Socialist International, wrote to the sp leadership to prevent it. At the meeting of the NEC in July 1935, the factions reached what Thomas called "an amicable agreement between the national executive committee and the New York state committee which has eliminated the danger of a split in the Socialist Party of the United States."138 The NEC agreed that "advocates of violence and communism" were ineligible for party membership, including those who supported "violent insurrection" or "dictatorship or abandonment of democracy either as a fact within the Party or as an ideal method of achieving socialism."

135. "Statement to the National Executive Committee...," 6 March 1935, reel 30, spP.

136. Revolutionary Policy Publishing Association, "Evaluation of the Meeting of the National Executive Committee, Buffalo, March 22-24, 1935," [April 1935?], reel 30, sp P.

137. See Kipnis, American Socialist Movement, Chap. 18.

138. Friedrich Adler to Comrades Oneal, Thomas, and Senior, 16 July 1935, NTP; Thomas to Adler, 25 July 1935, NTP. 
It also forbade the "subjugation of the Party to bureaucratic, mechanical discipline from abroad such as that imposed by the Third International." 139

The truce was temporary. In a pamphlet, the RPPA denounced the NEC, stating "that the right wing in the party has finally won a complete rout" and adding that "we can truly say that the S.P. has been handed over to the most conservative representatives of socialism." The pamphlet called on leftists in the SP to make a "complete break with the policies of the 'Militants' that have led to the present catastrophe" and instead support the RPPA's program. ${ }^{140}$

In October, the New York State sp tried to expel a left winger, Abe Kruger, for "the advocacy of Communism." When the Central Committee of the New York City party refused to go along, the Old Guard in the state leadership threatened to re-organize the city local. ${ }^{141}$ In November, Thomas wrote that, from his perspective, "the Old Guard, many of whom have done fine work in their day, have gone crazy or sour, or something." In an attempt to keep control of the SP, he complained, they were "deliberately trying to force me and a lot of other folks out of the Party or into a position of complete incompetence in the Party." ${ }^{42}$ In December 1935, Thomas told the New York Times that "the Old Guard have read themselves out of the party." He added, "If they want to be officers of any organization in the future, they will have to set up their own organization. And that organization will be a rival organization of the Socialist party." 143

This civil war within the Socialist Party reached its height in 1936. In January the national leadership suspended the New York State's party charter, essentially splitting the organization. In February, both Thomas and the Old Guard claimed the loyalty of the majority of the SP membership. ${ }^{144}$ Later that month, the official Socialist Party, under Thomas' control, accused the Old Guard of supporting the re-election of President Roosevelt: "No Socialist can tolerate a group who seek the re-election of Roosevelt, author of the greatest peacetime war budget, relief-slasher, and protector of American capitalism. There is no doubt that the Old Guard is out of the Socialist party; it is out of the Socialist movement as well." ${ }^{145}$

139. Revolutionary Policy Publishing Association (RPPA), “The N.E.C.: Neither 'Practical' Nor 'Just," August 1935, reel 31, spP.

140. RPPA, "The N.E.C."

141. "From Our Viewpoint," Socialist Appeal, October 1935.

142. Norman Thomas to Art Young, 20 November 1935, NTP.

143. “Thomas Declares War on Old Guard," New York Times, 12 December 1935.

144. "Left Wing Socialists Deny ‘Old Guard’ Lead,” New York Times, 16 February 1936.

145. Socialist Call quoted in "Radical Socialists to Oppose Roosevelt," New York Times, 23 February 1936. The Old Guard denied they supported Roosevelt: see "Old Guard Socialists Disavow Roosevelt," New York Times, 24 February 1936. 
The Old Guard coalesced into the Social Democratic Federation, based on the repudiation of the 1934 Declaration of Principles. Old Guard stalwarts such as Sidney Hillman's Amalgamated Clothing Workers, David Dubinsky's International Ladies' Garment Workers' Union, Theodore Debs, James H. Maurer, and Abraham Cahan sent messages of support to the new organization. ${ }^{146}$ That the SDF was a halfway house to the outright bourgeois liberalism of La Guardia and Roosevelt was evident in its support of the American Labor Party, which had been formed to channel labour support to Roosevelt without supporting the Tammany Hall-dominated Democratic Party. ${ }^{147}$

The SP's membership declined from almost 21,000 in 1934 to less than 12,000 in 1936; at the same time, the CP's membership climbed from 26,000 to $41,000 .{ }^{148}$ The defection of the Old Guard left the Militants in control of the party at the 1936 sp convention in Cleveland. To their right were the remaining supporters of the Old Guard, particularly Dan Hoan in Wisconsin and others in Connecticut, Massachusetts, New York, and Pennsylvania. With the Old Guard gone, Militants Jack Altman and Paul Porter were on the right of the rump SP while fellow Militants Gus Tyler and Herbert Zam staked out ground on the party's left wing. In the aftermath of the Cleveland convention, the RPPA dissolved itself because the Militants had gained power. ${ }^{149}$

Trying to steer the ship with so many disparate tendencies was Norman Thomas. The political questions that had roiled the Sp for the past several years had not been resolved, and a significant section of the rank-and-file was to the left of the party leadership - except Thomas, Altman, and other leaders could no longer use the Old Guard as an excuse for their policies. The Old Guard included many experienced organizers and other SP apparatchiks, and their defection left a gap in the party machinery. In short, the SP in 1936 was in organizational and political limbo. The party was trapped between the Scylla of Roosevelt, La Guardia, and Lewis on one side and the Charybdis of the Communist Party on the other. As the 1930s progressed and these two obstacles converged, the Socialists found it almost impossible to chart an independent course as the SP hemorrhaged leaders and rank-and-file militants alike to the Democratic Party, the Congress of Industrial Organizations, or the Communist Party. This provided the organizations to its left the opportunity to grow at the SP's expense.

This situation was not unique to the United States. Many countries saw a growth in left-wing social democracy. What was unique to the United States

146. New Leader, 30 May 1936.

147. Shannon, Socialist Party of America, 242-246; Frank A. Warren, Alternative Vision: The Socialist Party in the 1930's (Bloomington: Indiana University Press, 1974), 11; Bell, Marxian Socialism, 168-170.

148. Shannon, Socialist Party of America, 250; Klehr \& Haynes, American Communist Movement, 73, 85.

149. Francis A. Henson to “Dear Comrade," 29 April 1936, box 22, folder 9, DBP. 
was how the left reacted to this. To take one example, in Spain, the Communist Party (PCE) was the biggest beneficiary, growing from 8,800 members in April 1931 to 100,000 in June $1936 .{ }^{150}$ The Spanish followers of Bukharin's Right Opposition and the former supporters of Trotsky's Left Opposition formed (against Trotsky's advice) the Party of Marxist Unification (POUM), which claimed tens of thousands of members in late 1936. These developments had profound effects in the Spanish Civil War as the PCE and POUM built a popular front instead of fighting for working-class power. For another example, in Canada, where the stakes were less urgent than in Spain, no significant proBukharin presence existed, and the supporters of Trotsky split over how to react to the development of the CCF. By the late 1930s, the CPC and the CCF remained the strongest left-wing parties, although the CCF had eclipsed the CPC. Thus, developments in the left in the United States should be seen not as an inevitable outcome but as one possibility, shaped by political struggle.

While it goes without saying that I am responsible for all mistakes in this article, it should also go without saying that all insights or original ideas were a result of collaboration and discussion. I wish to thank the following people, who took the time to discuss my research, some of whom read multiple drafts: Don Andrews, Helene Brosius, Alison Dundy, Maria Gianotten, Mike Goldfield, Richard Genova, Ed Kartsen, Jason Martinek, John Morgan, Bryan D. Palmer, James Robertson, Charles Smith, Jeff Taylor, Emily Turnbull, and Skye White, as well as the anonymous reviewers of Labour/Le Travail. A historian without archives is truly a fish without water, and thus I wish to thank the Prometheus Research Library, the New York Public Library, and Tamiment Library. I also wish to thank the Reference and Interlibrary Loan staff at Guarini Library, New Jersey City University. Finally, I wish to the acknowledge the Dean's Office of the William J. Maxwell College of Arts and Sciences, New Jersey City University, for giving me release time to work on this article. 